\title{
Irena Teleżyńska
}

irenaantoninate@gmail.com

Instytut Etnologii i Antropologii Kulturowej

Uniwersytet Warszawski

\section{ZESLANIE JAKO WYZWOLENIE - NARRACJE Z HUCULSZCZYZNY}

\section{Deportation as Liberation: Narratives from the Hutsul region, Ukraine}

Streszczenie: Artykuł oparty na badaniach przeprowadzonych na Huculszczyźnie koncentruje się na narracjach osób zesłanych na Sybir w latach 1946-1952. Wyróżniam konstruowany przez rozmówców schemat narracyjny: (1) ukazanie życia przed wywózką jako bardzo ciężkiego i pozbawionego sprawczości ze względu na zmagania ruchu partyzanckiego z radzieckim okupantem, (2) moment wywózki opisywany zdawkowo, jako „ucięcie nożem“ i przeniesienie do nowej rzeczywistości, (3) przedstawienie codzienności na zesłaniu jako z początku niezwykle trudnej, ale z czasem, dzięki pracy, okiełznanej, gdzie można wieść jak najbardziej „,normalne“, a nawet dostatnie życie. Wskazuję również przyczyny, ze względu na które te narracje są tak odmienne od opowieści o represjach sowieckich spotykanych na gruncie polskim, skupiających się na traumie i martyrologii.

Słowa kluczowe: zesłania, deportacje, Huculszczyzna, Sybir, narracja, praca, pamięć, trajektoria.

Abstract: This article, based on my fieldwork conducted in the Hutsul region (Ukraine), focuses on narrations of people deported to Siberia between 1946 and 1952. I propose the following scheme of their narrative: (1) showing the life before the deportation as extremely difficult and depriving of agency due to the struggle of the partisan movement with the Russian occupying power, (2) the moment of deportation described succinctly, as a definite and abrupt end of one reality and beginning of 
another, (3) portraying the every-day life after the deportation as initially extraordinarily hard, but tamed with time (life led after the deportation became 'normal' and even affluent). I also indicate why these narrations are so different from the Polish stories of the Soviet oppression which focus on trauma and martyrology.

Keywords: deportations, repressions, the Hutsul region, Siberia, narrations, memory, trajectory. 


\section{Wstęp - kontekst polski}

W polskim dyskursie historycznym oraz przekazie kulturowym przymusowe przesiedlenia ${ }^{1}$ na Sybir $^{2}$ są silnie obecne. Wyobrażenia o zesłaniach tworzone są już na etapie edukacji szkolnej i kształtują je zarówno trzecia część Dziadów Adama Mickiewicza, jak i Inny świat Herlinga Grudzińskiego $^{3}$. Częścią tego dyskursu są również rozmaite instytucje zajmujące się upamiętnianiem, archiwizacją czy promowaniem wiedzy o represjach ZSRR wobec Polaków ${ }^{4}$ oraz oczywiście naukowcy. Polscy antropolodzy i antropolożki, badając narracje związane z deportacjami na Sybir (Kość

${ }^{1}$,W trakcie prowadzonych dotychczas badań nad przymusowymi przesiedleniami wypracowany został jednolity korpus pojęć służących do opisu tego zjawiska [...] Zacznijmy od omówienia problemu specyfikacji rozmaitych form przesiedlenia [...]. Najczęściej wyodrębnia się trzy takie formy - są to deportacje, zesłania oraz wysłania. Co do deportacji to jest ona definiowana jako zespół zjawisk obejmujących przymusowe wysiedlenia wielkich grup ludności do wyznaczonych [...] miejsc pobytu w trybie postanowienia administracyjnego bądź sądowego w rezultacie zastosowania terroru. Zesłania to przymusowe osiedlenia we wskazanym miejscu, często połączone z obowiązkiem pracy, będące następstwem wyroku sądowego albo decyzji administracyjnej. Wysłania zaś są [...] charakteryzowane jako »przymusowe wydalenia z miejsc dotychczasowego zamieszkania osób uznanych za niebezpieczne, połączone z nakazem przebywania w pewnych miejscowościach« (Ciesielski, Hryciuk, Srebrakowski 2003:8). Wszystkie trzy formy przesiedlenia mogą obejmować pobyt stały lub tylko okresowy, obliczony na określona liczbę miesięcy lub lat. [...] Omawiane przeze mnie zjawisko - ze względu na jego masowy charakter - uznać by zatem należało za deportacje. Świadoma tych dystynkcji pojęciowych określenia »deportacja« będę jednak używać wymiennie z innymi terminami, takimi właśnie jak »zesłanie«, »wysłanie«, a także »wywózka«, »zsyłka«, »wygnanie«, »wysiedlenie«, »przesiedlenie« itp." (Rzepkowska 2009: 10-11). Wszystkie powyższe uwagi odnoszą również do mojego terenu badań i niniejszej publikacji.

${ }^{2}$ Pojęcia „Sybir” używam zgodnie z definicją Aleksandry Rzepkowskiej, która pisała o doświadczeniu polskich zesłańców: „Termin ten nie jest także równoznaczny z geograficznie rozumianą Syberią, oznacza bowiem terytorium o dużo większej powierzchni, obejmujące na przykład Kazachstan czy Uzbekistan, a więc obszary, które stanowiły - obok północnych rejonów Rosji - miejsce przymusowego pobytu polskich zesłańców. Ze względu na wymienione różnice znaczeniowe będę się konsekwentnie posługiwała nazwą »Sybir« a nie »Syberia«, tak w sensie przestrzennym, jak i symbolicznym - odnoszącym się do biograficznego wymiaru doświadczenia deportacji” (Rzepkowska 2009:9).

${ }^{3}$ Choć jest to przykład literatury łagrowej, a nie zesłańczej, na lekcjach języka polskiego w liceum zazwyczaj mówi się zbiorczo o represjach systemu sowieckiego, nie wprowadzając szczególnego rozróżnienia na łagry i zesłania.

${ }^{4}$ M.in. Związek Sybiraków, Centrum Dokumentacji Zsyłek, Wypędzeń i Przesiedleń, Polskie Towarzystwo Ludoznawcze oraz Ośrodek „Karta“. 
Irena Teleżyńska

2008; Kudela-Świątek 2013; Rzepkowska 2009), podkreślają głównie ich wymiar martyrologiczny, traumę związaną z tym doświadczeniem oraz religijność jako kluczowy aspekt kreowania tożsamości Zesłańców ${ }^{5}$.

W aspekcie patriotycznym i martyrologicznym przywiązanie do miejsc zamieszkiwanych na wygnaniu jest zawsze oceniane nieprzychylnie jako zwątpienie w możliwość powrotu do ojczyzny oraz akceptacja nowej sytuacji, a co znacznie gorsze, jako przyznanie, że na Sybirze można żyć i to całkiem znośnie. Obie postawy są niezgodne z etosem Polaka-zesłańca, nakazującym bunt jako kardynalną postawę życiową. Przystosowanie do nowych warunków oznacza bowiem zgodę na swój los, oznacza prócz tego stabilizację - zamiast marzenia o powrocie do ojczyzny oraz, w konsekwencji, bycia ciągle gotowym do drogi (Rzepkowska 2009: 145).

Podobnie pisze o tym Katarzyna Kość-Ryżko:

Przywiązanie do wiary katolickiej oraz religijność deportowanych niejednokrotnie stanowiła główne źródło uzasadnień celowości i sensowności ich losów. W trudnych warunkach życia stosunkowo często budziła się potrzeba odświeżenia mitu Polaka-męczennika (bojownika za wolność i niepodległość ojczyzny) oraz Polski jako narodu wybranego (Kość 2008: 104).

Istotna jest również rola ,świadka historii” - rozumiana zarówno jako obowiązek wobec tych, którzy nie przeżyli, aby zostali zapamiętani, jak i wobec przyszłych pokoleń, dzięki którym przetrwa pamięć. Ta specyfika polskich narracji związana jest również z pozycją klasową opowiadających. Deportowani Polacy wywodzili się przeważnie z warstw urzędniczo-inteligenckich/ziemiańskich, i to ich głos kształtuje dyskurs o zesłaniu. To klasa wyższa naznacza samą siebie jako ostoję polskiego patriotyzmu, powtarzając romantyczny model Polski i Polaków jako Chrystusa narodów. Jest to opowieść ludzi z wysokim kapitałem kulturowym i symbolicznym, którzy nierzadko dopiero na zesłaniu zetknęli się po raz pierwszy z pracą fizyczną. Doświadczenie zesłania jest (i niejako musi być) opisywane negatywnie. W narracjach dotyczących okresu II Wojny Światowej Rokuszewska-Pawełek wskazuje na:

${ }^{5} \mathrm{~W}$ niniejszej pracy, określając moich rozmówców mianem Zesłańców czy Łagierników, używam wielkiej litery - wybór ten podyktowany jest głównie szacunkiem do osób, które podzieliły się ze mną swoimi historiami, jak również stosowaniem tego określenia jako pewnej kategorii analitycznej (patrz niżej). 
monolityczność martyrologicznego obrazu, w którym celebrowana jest wartość ofiary, niezłomny opór i walka oraz wiara w człowieka, ale także jego jednostronność z punktu widzenia ocen moralnych: jednoznacznego podziału na kata i ofiarę, z jasną granicą między dobrem i złem, „nami” i „nimi” (Rokuszewska-Pawełek, 2002: 105).

Jednak w trakcie moich badań ${ }^{6}$ na Huculszczyźnie ${ }^{7}$ musiałam zweryfikować moje dotychczasowe wyobrażenia o zesłaniach na Sybir. Rozmówcy uświadomili mi, że narracja dotycząca zesłania może być konstruowana radykalnie odmiennie; pokazali, że istnieje zgoła inny sposób przeżywania i pamiętania tych doświadczeń. Taki, w którym jest miejsce na to, co dobre i co złe, na cierpienie i na szczęście, łzy i śmiech. Taki, w którym pobyt na Sybirze nie jest czasem straconym, biernym czekaniem i negacją, lecz działaniem, samo-konstytuowaniem się przez pracę, czasem odkrywania nowych możliwości. Te rozważania doprowadziły mnie do trzech pytań: jak swoje doświadczenie rozumieją sami Zesłańcy; dlaczego to samo doświadczenie tak odmiennie zachowało się w pamięci dwóch różnych narodów; dlaczego dla Polaków Sybir był traumą, a dla Hucułów wyzwoleniem? Na nie postaram się odpowiedzieć w niniejszym artykule.

\section{Rys historyczny}

II Wojna Światowa nie skończyła się dla Ukrainy Zachodniej ${ }^{8}$ w 1945 roku. Choć propaganda ZSRR przedstawiała to wydarzenie jako „zjednoczenie” z Ukrainą Radziecką i „bratnim” narodem rosyjskim, przyniosło ono nową falę represji i cierpień. „Średnio na każdy dzień z pierwszych

${ }^{6}$ Niniejsza praca jest wynikiem badań terenowych prowadzonych od lipca 2014 roku do listopada 2015 r. w ramach laboratorium: „Huculszczyzna - obszary pamięci” pod kierownictwem dr Tadeusza Baraniuka oraz mgr Bartłomieja Chromika. Podczas 5 wyjazdów spędziłam łącznie 10 tygodni w terenie i przeprowadziłam trzydzieści siedem pogłębionych wywiadów etnograficznych.

${ }^{7}$ Region określany przez etnografów jako Huculszczyzna znajduje się w środkowej i wschodniej części ukraińskich Karpat. Przecina granice obwodów Iwano-Frankowskiego, Zakarpackiego i Czerniowieckiego. Moje badania skupiły się w „sercu” galicyjskiej Huculszczyny - miasteczku Wierchowina oraz okolicznych wsiach.

${ }^{8}$ Huculszczyzna jest częścią Ukrainy Zachodniej. Pisząc o historii tej drugiej, odnoszę się więc również do terenu moich badań. 
dwudziestu miesięcy władzy radzieckiej na Ukrainie Zachodniej przypadało 500 potyczek między UPA i wojskiem radzieckim" (Hrycak 2000: 278). Władza Związku Radzieckiego, choć obejmowała całe terytorium współczesnej Ukrainy, na wsi była nierzadko pozorna - ruch partyzancki, często wspierany przez ludność wiejską, zszedł do głębokiego podziemia, nie zaprzestając walki zbrojnej, chowając się w lasach. Sowietyzacja przeprowadzana była z wykorzystaniem terroru i przemocy: aresztowania, łagry, kolektywizacja, ,samolikwidacja” Kościoła greckokatolickiego $^{9}$ oraz masowe deportacje na Sybir były elementami stalinowskiego reżimu (Hrycak 2000, s. 276-281). Masowe deportacje ${ }^{10}$ po zakończeniu II Wojny Światowej obejmujące Ukrainę Zachodnią odbywały się w trybie administracyjnym ${ }^{11}$ i miały charakter falowy: po największej z nich (Akcji Zachód 21.10.1947) tempo wywózek spadło, jednak ich strumień płynął nieustannie aż do 1952 roku.

Łącznie w latach 1944-1952 wywieziono z terenów Zachodniej Ukrainy 65906 rodzin - 203622 osoby, z czego z obwodu wołyńskiego - 21966 osób, drohobyckiego - 35623, lwowskiego - 42883, roweńskiego - 26131, stanisławowskiego (obecnie obwód Iwano-Frankowski) - 40692, tarnopolskiego - 32069, czerniowieckiego - 4298 (Stecenko 2007: 125).

Według oficjalnych dokumentów wysiedlenie na specposlenie [ros.] $]^{12}$ z Ukrainy Zachodniej (w latach 1944-1952) wraz z konfiskatą majątku objęło następujące grupy:

9 Została ogłoszona na zorganizowanym przez NKWD Soborze Lwowskim (8-10.03.946) wraz z „dobrowolnym“ przyłączeniem do Rosyjskiej Cerkwi Prawosławnej.

${ }^{10}$ Oczywiście deportacje w ZSRR zaczęły się o wiele wcześniej niż te omawiane przeze mnie i nie dotyczyły tylko terenów obecnej zachodniej Ukrainy. Pierwsze, w 1930 roku, tzw. zsyłka kułacka, związane były z przymusową kolektywizacją w ZSRR. Historiografia tematu jest niezwykle szeroka, jednak ze względu na potrzeby niniejszego tekstu posłużyć może jedynie do zarysowania historycznego tła wydarzeń. Szersze omówienie problemu deportacji w ZSRR zob. m.in. Masowe Deportacje Ludności w Związu Radzieckim (Ciesielski, Hryciuk, Srebrakowski 2004), Narody Ukrainy w „Osoboj papke Stalina”(Bugaj 2006), Ukrajina 1920-1980-ch: deportaciji, zastannia, wystannia (Wynnyczenko 1994), Against Their Will. The History and Geography of Forced Migrations in the USSR (Polian 2003, tabela ze spisem przymusowych deportacji w ZSSR tamże: 327-334).

${ }^{11}$ O prawnych podstawach zob. Ciesielski 2001, Wrońska 2007.

$12 \mathrm{O}$ specyfice statusów Zesłańców można przeczytać np. w: Masowe deportacje w ZSRR - charakterystyka wybranych aspektów zjawiska (Ciesielski 2001). 

a) rodziny „ounowców”13 lub ,aktywnych powstańców”;
b) rodziny powstańców aresztowanych oraz zabitych w starciach;
c) rodziny osób ukrywających się;
d) ,pomocników bandytów”;
e) kułaków oraz kułaków-nacjonalistów wraz z rodzinami (kurkuli-na- cjonaliści);
f) świadków Jehowy;
g) ,andersowców” - byłych żołnierzy Polskich Sił Zbrojnych z rodzi- nami;
h) ,elementy wrogie i szkodliwe"/,,antyradzieckie elementy".

Tak szeroko zakrojone kategorie sprawiały, że można było w nie wpisać prawie każdego obywatela ZSRR, od inteligenta jako wroga klasowego, przez ludzi wierzących, aż po osoby po prostu z punktu widzenia władzy niewygodne.

Choć istniał szereg wytycznych określających przebieg akcji przesiedleńczych - instrukcje określające „,normy” bagażowe, jedzeniowe, transportowe - praktyka często rozmijała się z duchem dokumentów i sprowadzała się do decyzji funkcjonariuszy kierujących wysiedleniem (Ciesielski 2001: 53). Aresztowania odbywały się zazwyczaj w nocy lub wczesnych godzinach porannych. Funkcjonariusze sowieccy przychodzili do chaty $\mathrm{z}$ nakazem wysiedlenia, dawali rodzinie czas na zebranie najpotrzebniejszych rzeczy, po czym zwozili wszystkich do punktu zbiorczego w danej wsi - najczęściej sil's'kiej rady lub szkoły. Następnym etapem drogi były pereselens'ki punkty ${ }^{14}$, zorganizowane w większych miastach, na przykład w Kołomyi. Zgromadzeni tam ludzie niekiedy musieli czekać kilka tygodni, a nawet miesięcy, na transport na Sybir. Po zebraniu kontyngentu Zesłańców ładowano do wagonów towarowych [towarniaki], których wyposażenie sprowadzało się do prycz, piecyka i wyciętej w podłodze dziury służącej potrzebom fizjologicznym - warunki te szczególnie dawały się we znaki w okresie wysyłek jesienno-zimowych. Norma jedzeniowa wynosiła 500 g chleba, 60 g ryby, 10 g tłuszczu i 10 g cukru - w praktyce sprowadzało się to

${ }^{13}$ Określenie ,ounowiec' stosowane było (bardzo rozciągliwie) zasadniczo w stosunku do członków i sympatyków działającej w podziemiu Organizacji Ukraińskich Nacjonalistów oraz partyzantów Ukraińskiej Powstańczej Armii” (Ciesielski, Hryciuk, Srebrakowski 2004: 279).

${ }^{14}$ Punkty zborne utworzono w styczniu 1949 r. (Ciesielski, Hryciuk, Srebrakowski 2004: 299). 
do zupy gotowanej na rybich głowach zwanej balanda lub pochlupka, wydawanej w czasie rzadkich postojów (Stecenko 2007: 124). W tych ekstremalnie ciężkich warunkach, w tłoku i głodzie, przychodziło spędzić Zesłańcom całe tygodnie. Wielu z nich umierało po drodze. Zwłoki wyrzucano z pociągów w środku stepu. Do dziś wielu z rozmówców nie wie, gdzie - i czy w ogóle - pochowano ich bliskich.

Przestrzeń zsyłek była ogromna. Miejsca zesłania rozciągają się od Uralu po Kamczatkę. Większość rozmówców została deportowana do Chabarowska, obwodu irkuckiego i Karagandy (dzisiejszy Kazachstan). Zesłani trafiali w miejsca, które można podzielić na trzy typy: wieś, miasto lub tajga. Po przyjeździe byli osiedlani zazwyczaj w barakach lub ziemiankach. Następnie musieli zgłosić się do lokalnej komendantury, gdzie podpisywali oświadczenie o przesiedleniu na wieczność ${ }^{15}$ - rozpis na vichnist'. Obejmował ich zakaz opuszczania miejsca osiedlania, obowiązek meldowania się [vidmichatysya] w lokalnym oddziale NKWD oraz obowiązek pracy. Kiedy po śmierci Stalina i upadku Berii reżim zelżał, z czasem zniesiono niektóre ograniczenia (np. częstotliwość meldowania się) oraz pozwolono wracać na Ukrainę - z początku w celach odwiedzin, a w 1957 roku na stałe, przy czym nadal z zakazem powrotu do rodzinnej wsi.

$\mathrm{Na}$ wsiach deportacje pozwoliły osiągnąć reżimowi radzieckiemu czworakie cele. Po pierwsze, były ogromnym ciosem zadanym ruchowi partyzanckiemu, dla którego wieś stanowiła oparcie (opieka lekarska, nowi rekruci, łączność) oraz zaplecze materialne (jedzenie, odzież), były też sposobem zastraszenia lokalnych mieszkańców i zniechęcania ich do wspierania partyzantów. Po drugie, rozkułaczenie wsi pozbawiło ją naturalnych liderów. Najbardziej aktywni gospodarze, którzy potencjalnie mogliby stawiać opór kolektywizacji, zostali zesłani. Po trzecie, konfiskowane majątki Zesłańców - ziemie, trzoda, inwentarz, budynki - objęte zostały kolektywizacją i weszły do systemu kołchozowego. Po czwarte, masowe wysiedlenia były również swoistą strategią ekonomiczną, która kierowała siłę roboczą w nieprzystępne i odległe miejsca ZSRR, umożliwiając ich eksploatację i „rozwój”.

15 „6 kwietnia 1950 r. Rada Ministrów ZSRR wydała rozporządzenie, na mocy którego wszystkim specjalnym przesiedleńcom z tzw. Ukrainy Zachodniej, wywożonym dotąd na określony czas, zmieniono termin zesłania na dożywotni” (Ciesielski, Hryciuk, Srebrakowski 2004: 298). 


\section{Badania}

Podczas badań na Huculszczyźnie prowadziłam rozmowy zarówno z osobami, które znalazły się na Sybirze w wyniku masowych deportacji, jak i z tymi, które były skazane na przymusowe roboty w łagrach. Im bardziej zagłębiałam się w kolejne rozmowy, tym bardziej ukazywała mi się odmienność tych dwóch typów doświadczeń. Choć początkowo sądziłam, że można je rozpatrywać łącznie, teraz uważam to za błąd. Opierając się na zebranym materiale, mogę stwierdzić, że doświadczenia Łagierników i Zesłańców są odmienne i w zasadzie nieporównywalne, a rozpatrywanie ich w kontekście licytacji cierpienia również wydaje się nieadekwatne. Łączenie tych dwóch grup i zakwalifikowanie ich do jednej kategorii „Sybiraków" jest, moim zdaniem, błędem.

Większość Łagierników, z którymi rozmawiałam, walczyła w UPA i to właśnie za tę działalność zostali przez Rosjan skazani na przymusową pracę w obozach. Ich los był wynikiem podejmowanych przez nich samych działań:

Bóg jak stworzył człowieka, to dał mu rozum i wolną wolę. Bóg, mówię, nie Stalin, nie Hitler - co tylko „tak rób, jak ja powiedziałem, a dalej nie” - krok w lewo, krok w prawo, nie ma. A Bóg dał rozum i wolną wolę. My przecież wiedzieliśmy dobrze, co nas czeka - jak nas nie zabiją, to czeka nas więzienie. Ale my to robiliśmy, szliśmy. Bóg nie weźmie cię za szyję, nie odciągnie i nie powie: „gdzie ty dziewczyno się pchasz?" [śmiech] ${ }^{16}$.

To właśnie owo poczucie sprawczości oraz idącej za nią odpowiedzialności za własne decyzje jest jednym z podstawowych czynników różniących wymienione wyżej grupy. Szerzej opiszę to zjawisko dalej, tu pragnę jedynie zaznaczyć, że Zesłańcy takiego poczucia nie mają. Kategorie kwalifikujące ludzi do zesłania były tak szerokie i nieokreślone, że praktycznie każdy mógł być nim objęty. Stąd też częste wśród nich przekonanie, że: ,po prostu za nic nas wzięli tu. Za nic, za nic to nie łatwo".

${ }^{16}$ Wszystkie cytaty, o ile nie zaznaczono inaczej, pochodzą z przeprowadzonych przeze mnie wywiadów od lipca 2014 do listopada 2015 roku. Zostały one nagrane na dyktafon, przetranskrybowane z języka ukraińskiego na polski alfabetem łacińskim, oddając fonetyczne brzmienie ukraińskich słów, a następnie przetłumaczone na język polski. Pełny spis wywiadów znajduje się w Archiwum IEiAK UW. 
Łagier był specyficzną formą więzienia, a przebywający w nim ludzie byli pod stałym nadzorem i kontrolą komendantów. Codzienność stanowiły skrajne warunki bytowe, wyniszczająca ponad siły praca i głodowe porcje jedzenia. Zesłańcy na Sybirze, szczególnie w pierwszych latach, również zmagali się z głodem i ciężkimi warunkami życiowymi, jednak nie odebrano im wolności oraz człowieczeństwa w tak wielkim stopniu jak Łagiernikom. Jedyną formą nadzoru było meldowanie w komendanturze, jedynym zakazem - zakaz opuszczania miejsca pobytu.

Przywieźli w taką tajgę, lasy, i oni [Rosjanie - I.T.] gdzieś pojechali jeszcze, tak... Przywieźli do lasu (...) na ziemi zostawili. - „Siadajcie. Róbcie co chcecie.“ Kto miał jakieś jedzenie to jadł, a jak nie miał to zdychali, umierali ludzie z głodu. Ale ludzie jedni drugim dawali, dzielili się.

Tam to już ludzie byli wolni. To nie tak jak w łagrze. Tam człowiek jest wolny, robi co chce.

Zdecydowałam się poświęcić niniejszą pracę Zesłańcom, gdyż moją uwagę zwróciła ich nieoczywistość jako grupy. O ile Łagierników rozmaite dyskursy wpisują w kategorie „bohaterów”, „bojowników o wolność”, „ofiar stalinowskiego reżimu”, a z drugiej strony: „bandytów”, „wrogów ojczyzny”, „zbrodniarzy”, o tyle Zesłańców trudniej jest sklasyfikować. Stanowią oni bardzo dużą, a jednocześnie niezidentyfikowaną grupę. Zsyłki osiągnęły tak masową skalę (por. Stecencko 2007), że trudno znaleźć wieś, z której nikt nie byłby deportowany ${ }^{17}$. Prowadzi to do paradoksalnej sytuacji, gdzie zesłani byli ,wszyscy i nikt". $Z$ jednej strony bycie na zesłaniu przyjmowane jest przez współmieszkańców wsi jako „normalne”, nieróżnicujące, powszechne doświadczenie, $\mathrm{z}$ drugiej zaś nie ma potrzeby mówienia i pamiętania o tym (zesłanie nie musiało być najcięższym doświadczeniem w życiu moich rozmówców). Brak również badań na ten temat, szczególnie badań antropologicznych ${ }^{18}$.

\footnotetext{
${ }^{17}$ Spotkałam się tylko z jednym takim miejscu na Huculszczyźnie - wsią Babin.

${ }^{18}$ Oczywiście historiografia przedmiotu jest ogromna, patrz przypis 10.
} 


\section{Narracje}

Choć podjęte przeze mnie badania są związane z ważnymi wydarzeniami historycznymi XX wieku, celem artykułu nie jest ich rekonstrukcja ani poszukiwanie prawdy historycznej. Obracam się w sferze interpretacji odczuć i przeżyć moich rozmówców, a nie w sferze faktów historycznych. Przedmiotem moich badań był sposób rozumienia oraz przedstawiania tych wydarzeń w narracjach kształtujących ludzką tożsamość. Narrację rozumiem zarówno jako sam sposób opowiadania, jak i

rozumienia świata przez ludzi. [...] Ta naturalność formy opowiadania, jako środka wyrażania myśli i przeżyć, nie wynika z natury samego procesu komunikacji, lecz jest efektem narracyjnego sposobu pojmowania świata, który z kolei wynika z narracyjnej struktury ludzkiej wiedzy o świecie (Trzebiński 2002: 17).

Za pośrednictwem narracji jednostka konstruuje świat znaczeń, chaos bodźców wynikający $\mathrm{z}$ bycia zanurzonym $\mathrm{w}$ świecie musi zostać jakoś nazwany i usensowiony - przekuty w doświadczenie. To konstruowanie odbywa się na zasadzie relacji zwrotnej: podmiot-świat. $Z$ jednej strony chaos zostaje ujęty w strukturę, $z$ drugiej - sposób jego ujęcia jest również źródłem informacji na temat podmiotu dla odbiorcy, do którego kierowana jest narracja (przy czym tym odbiorcą może być również sam podmiot). Za pośrednictwem autonarracji - opowieści biograficznej-nadajemy sens swoim przeżyciom, przekształcając je w doświadczenia, które z kolei stają się markerami naszej indywidualności. Narracje są więc również formą wyrażania pamięci indywidualnej, a raczej jej (re)konstruowania wobec własnej tożsamości. „Relacja pomiędzy tożsamością i pamięcią ma charakter cyrkularny: z jednej strony to, co pamiętamy, zależy od tego, kim jesteśmy i za kogo się uważamy, z drugiej zaś nasza tożsamość uwarunkowana jest przez nasze wizje przeszłości” (Saryusz-Wolska, Traba 2014: 493).

W niniejszym artykule podążam za tropem wyznaczonym przez Aleksandrę Rzepkowską, która znajduje wspólny mianownik dla wielu poszczególnych opowieści o zesłaniu dzięki kategorii meganarracji o doświadczeniu zsyłki. Pisze ona: 
Rzecz jasna każda z tych relacji stanowi ze swej natury zjawisko jedyne i niepowtarzalne (wyznaczane przez konkretną sytuację egzystencjalną jej autora oraz utrwalające jego subiektywny sposób widzenia i odczuwania świata). Zarazem jednak każda z nich wyraża też pewną prawdę ponadindywidualną, wynikającą z masowego charakteru tych wydarzeń, jakimi były deportacje Polaków na Sybir. Rozpatrywane we wzajemnych interakcjach i powiązaniach, wszystkie te relacje składają się przeto na jedną i tę samą „wielką opowieść”, ewokującą wspólnotę losu oraz pamięci członków zbiorowości sybirackiej, ich wspólne uwikłanie w dzieje. (Rzepkowska 2009: 14).

Określając rozmówców mianem Zesłańców czy Łagierników, daleka jestem od ich esencjalizowania. Zdaję sobie sprawę, że wszystkie zebrane przeze mnie narracje są unikatowe, niemniej postanowiłam skupić się na wymiarze grupowym ich opowieści, toteż te określenia są dla mnie pewną kategorią analityczną związaną z wspomnianą wyżej meganarracją. Z tego względu nie przeprowadzam szczegółowej analizy pojedynczych biografii, tylko stosuję podejście problemowe, rozpatrując konkretne zagadnienia, aspekty doświadczenia wywózki, szukając ogólniejszego schematu narracyjnego.

Z kilku względów rezygnuję w mojej analizie z używania kategorii traumy. Po pierwsze, narracje zawsze są konstruowane przez narratorów z perspektywy współczesnej i wątek przebytych cierpień nie jest tym, który chcieli w swoich opowieściach wyeksponować, znajdując dla nich inny sens. Skupiali się raczej na kreowaniu wizerunku pracowitego Hucuła zdolnego znieść wszelkie przeciwności losu. Nie twierdzę, że na Huculszczyźnie - czy, szerzej, na Ukrainie - nie ma osób, które swoje doświadczenia rozumieją w sposób zbliżony do wywiezionych Polaków, jednak w trakcie moich badań takich osób nie spotkałam. Po drugie, nie mam kompetencji by oceniać, w jakim stopniu przeżycia związane z wywózką były raniące, trudne, czy też odbiły się na psychice moich rozmówców. Zdaję sobie sprawę, że sytuacja wywiadu narracyjnego często jest przedstawiana jako mająca również swój terapeutyczny wymiar, lecz, ponieważ nie jestem ani psychologiem ani terapeutą, nie roszczę sobie prawa do wypowiedzi dotyczących ówczesnych stanów psychicznych osób, które poznałam. Podczas wywiadów oczywiście współodczuwałam z moimi rozmówcami, choć jest dla mnie oczywiste, że nikt, kto sam nie przeżył zesłania, nie będzie w stanie w pełni zrozumieć tego doświadczenia. Wpisana jest $\mathrm{w}$ nie immanentna nieprzekazywalność, podobnie jak 
we wszystkie doświadczenia związane z wielkim cierpieniem. Sądzę, że nie jest to kwestia ograniczenia zdolności intelektualnych badacza, ale po prostu bariera wynikająca z braku takich przeżyć.

Ważnym aspektem dla rozumienia zebranego przeze mnie materiału jest fakt, że rozmówcy w momencie deportacji mieli od 5 do 17 lat. Byli dziećmi i tak funkcjonowali w relacjach z innymi. O tym kontekście nie należy zapominać, gdyż ma on ogromny wpływ na narracje, szczególnie na kwestię powrotu na Ukrainę ${ }^{19}$. Rozmówcy nie czuli tak silnego związku z ojczyzną, jak starsze pokolenie, zazwyczaj nie chcieli do niej wracać, a robili to głównie ze względu na swoich rodziców. Niestety dostęp do relacji ,głów rodzin” nie jest już możliwy. Badania porównawcze tych dwóch grup byłyby nieocenionym wkładem w rozważania na temat pamięci i narracji. Aleksandra Rzepkowska podczas swoich badań nad zesłaniami w Polsce rozmawiała $\mathrm{z}$ osobami, które również przeżyły je w bardzo młodym wieku. Określa to pokolenie (za Susan Rubin Suleiman) jako pokolenie 1,5 - pomiędzy pamięcią autobiograficzną a postpamięcią.

Suleiman wprowadziła to określenie na użytek analiz, których przedmiotem były wspomnienia dzieci ocalałych z Holocaustu. Wyjątkowość ich sytuacji biograficznej i egzystencjalnej polegała na tym, że mimo iż były one bezpośrednimi świadkami Zagłady, były zbyt niedojrzałe, by w pełni zapamiętać oraz pojąć sens tego, co się wówczas działo. W ich postrzeganiu tamtego okresu perspektywa pamięci autobiograficznej (właściwej pierwszemu pokoleniu świadków Zagłady) nieuchronnie miesza się zatem z perspektywą pamięci przejętej czy zapożyczonej, odpowiadającej drugiemu pokoleniu narodu żydowskiego, które bezpośrednio nie doświadczyło Szoah (Suleiman 2002: 277-282). Moi rozmówcy znajdowali się w analogicznym położeniu, co pozwala sądzić, iż liczne zawarte w ich relacjach treści mają charakter pozaautopsyjny, a więc że pochodzą nie z ich własnej pamięci, lecz zostały zaczerpnięte od innych (por. Kowalska-Leder 2005) (Rzepkowska 2008: 18).

W moim artykule nie posługuję się jednak pojęciem pokolenia 1,5. Choć jest ono adekwatne dla rozmówców łódzkiej badaczki, którzy deportowani byli w latach 1940-41, a powrócili w 1946 roku, to jednak nie

${ }^{19}$ Ze względu na ograniczoną objętość tego artykułu pomijam w nim kwestię powrotów Zesłańców na Ukrainę. 
wydaje mi się przystające do opowieści moich rozmówców, którzy - choć byli wywiezieni jako dzieci - na Sybirze stali się dorosłymi. Większość z moich rozmówców spędziła tam około 10 lat, więc trudno w tym wypadku mówić o ,pozaautopsyjnym charakterze” ich doświadczeń.

Drugim bardzo istotnym aspektem, który należy wziąć pod uwagę, jest sytuacja ekonomiczna osób żyjących na wsi huculskiej w pierwszej połowie XX wieku. Różnice majątkowe między ludźmi były ogromne. Choć niewielu $\mathrm{z}$ nich było bardzo bogatych, w oczach tych skrajnie biednych nawet ci, którzy posiadali niewiele więcej, już byli bardzo zamożni.

(A za co was przesiedlili?) ${ }^{20}$ Za to, że byliśmy kułakami. Mieliśmy dwadzieścia owiec, trzy krowy i konia.

Moi rozmówcy wspominają ten okres jako szczególnie ciężki; przypadał na ich dzieciństwo, z którego wyzuła ich bieda. Często wiązało się to z niemożnością chodzenia do szkoły i zdobycia edukacji, gdyż trzeba było pomagać przy gospodarstwie.

Kiedyś życie było ciężkie. Biedowaliśmy, paśliśmy owce, bydło. Wiecie, nikt nie żałował dzieci, aby tak jak teraz mogły pospać, posiedzieć, pobawić się... Musieliśmy rano, ze wschodem słońca iść [na połoninę, paść - I.T.]. Rosa nie rosa, deszcz nie deszcz - musieliśmy pójść. Zaczęłam chodzić do szkoły jak miałam 6 lat, ale trzeba było paść owce, więc [rodzice - I.T.] zabrali mnie ze szkoły.

\section{Kontekst huculski}

Zebrany przeze mnie materiał można analizować posługując się kategorią trajektorii, a raczej jej specyficznego przepracowywania. Samo pojęcie przedstawił Anselm Strauss, który rozumiał je bardzo konkretnie - jako trajektorię choroby - i wykorzystywał w swoich badaniach nad umierającymi (Rokuszewska-Pawełek 2002: 71-75). Fritz Schütze stworzył uogólnioną koncepcję trajektorii, rozszerzając ją na różne typy doświadczeń biograficznych - niekoniecznie związanych z kontekstem

\footnotetext{
${ }^{20} \mathrm{~W}$ nawiasach okrągłych umieszczam pytania zadawane przeze mnie w czasie rozmowy.
} 
medycznym - które jednak wiążą się z cierpieniem i utratą kontroli nad swoim życiem. Niemiecki socjolog wyróżnił również strukturę sekwencyjną procesów trajektoryjnych, którą Alicja Rokuszewska-Pawełek ujmuje następująco:

(1) gromadzenie się potencjału trajektoryjnego; (2) przekraczanie granicy pomiędzy intencjonalnym i uwarunkowanym stanem psychicznym; (3) próba osiągnięcia nowej, chwiejnej równowagi radzenia sobie z życiem codziennym; (4) destabilizacja chwiejnej równowagi życia codziennego (,wpadnięcie w wir"); (5) załamanie się organizacji życia codziennego i orientacji wobec samego siebie; (6) próby teoretycznego przepracowania trajektorii - próby racjonalizacji i pogodzenia się z nią; (7) praktyczna praca nad trajektorią i uzyskaniem nad nią kontroli oraz/lub próby uwolnienia się od niej (Rokuszewska-Pawełek 2002, 80-82).

Sama koncepcja nie jest wolna od prób psychologizacji (czego w niniejszym artykule pragnę uniknąć), niemniej dobrze opisuje doświadczenie zesłania. W zebranym przeze mnie materiale wyróżniam trzy najważniejsze elementy schematu narracyjnego huculskich opowieści o zesłaniach: (1) ukazanie życia przed wywózką jako bardzo ciężkiego i pozbawionego sprawczości ze względu na zmagania ruchu partyzanckiego z radzieckim okupantem, (2) moment wywózki opisywany zdawkowo, jako „ucięcie nożem“ i przeniesienie do nowej rzeczywistości, (3) przedstawienie codzienności na zesłaniu jako z początku również niezwykle trudnej, ale z czasem, poprzez pracę, okiełznanej, gdzie można wieść jak najbardziej „normalne”, a nawet dostatnie życie.

Dla interpretowania narracji Zesłańców kluczowe jest zrozumienie atmosfery powojennej wsi huculskiej. Walki na Ukrainie Zachodniej nie zakończyły się, a władza Związku Radzieckiego na tym obszarze była ograniczona. Ukraińska Powstańcza Armia stawiała aktywny opór okupantom. W narracjach rozmówców okres ten przedstawiany jest jako niezwykle ciężki. Nie angażując się po żadnej ze stron, przedstawiają wizję dwóch zewnętrznych, wrogich sił, pomiędzy którymi znalazła się ukraińska wieś. W narracjach huculskich Zesłańców ten konflikt nie nosi znamion ideologicznych: to nie Ukrainiec walczy z Rosjaninem ani nacjonalista $\mathrm{z}$ komunistą, tylko dwie bliżej nieokreślone grupy. Obie wykorzystują mieszkańców wsi do walki z przeciwnikiem. 
Ruskim daj, tym daj. To nie było tak, że „proszę”. To teraz jest w porządku. Teraz mówią, że bieda. Jaka teraz bieda niby? Kto ci w okna stuka? Położyłeś się spać to spokojnie sobie śpisz i nic. A wtedy, jak tylko dom zamknąłeś, to już stukają, nie wiesz nawet którzy. Przyszli ci, to stukają. A potem przyjdą tamci. A jak zejdą się wszyscy razem, to już się biją. To niebezpiecznie było. Bardzo niebezpiecznie było.

Rozmówcy nie czują się traktowani podmiotowo, jako jednostki mogące opowiedzieć się po którejś ze stron. Są postrzegani raczej jako źródło zasobów:

Bandyci przyszli jeść - to co? Ty mu nie dasz? On sam bierze! [...] Tak. Oni sami biorą. Wtedy było tak, że mama miała dużo dzieci, a oni już... Mama jedzenie chowała. O tak, wiecie, piece były takie, to tak tam chowaliśmy jedzenie. I dzięki temu zostało trochę jedzenia. A tak to przyjdą, biorą sało, biorą bużenicę, biorą wszystko. To nie było tak, żeby nie wzięli. Sami biorą.

Działania partyzantów nie ograniczały się to tylko do zabierania jedzenia. Również ludzie byli postrzegani jako coś, co można było wziąć i wykorzystać do swoich celów.

To mój brat był [w UPA - I.T.]. Obaj byli w partyzantce - to nie było tak, że ty chcesz albo nie chcesz; zabrali - poszli. Nie chcesz - strzelają w... To przymusowe było. To nie było tak dobrowolnie.

Codzienność tamtych czasów przedstawiana jest jako życie w ciągłym strachu o swój los. Banderowcy przedstawiani są jako nie ponoszący odpowiedzialności za swoje czyny. To nie oni muszą się mierzyć z konsekwencjami własnych działań; odpowiedzialność za nie spada na całą wieś, którą spotykają represje ze strony moskali.

Tak. Tam co... no na przykład przyszedł, ale bandyci przyszli jeść - to co? Ty mu nie dasz? On sam bierze! Widzicie. A to tacy byli... oni mieli iść, a... jak oni mieli czym wykupić się to prostych ludzi [posyłali - I. T..] Prości oni byli, niepiśmienni. Gdzie oni by do tego?

To prości ludzie - nehramotni - byli karani przez reżim. 
W zebranych przeze mnie narracjach obrazu życia przed wysyłką dopełniają sposoby przedstawiania sąsiadów. Wieś jawi się jako pełna donosicieli - kogoś można było obhovoryt', zarówno przed banderowcami, jak i moskalami. W przypadku informowania sowietów podaje się głównie motywacje ekonomiczne. Wojna zadała wsi ogromny cios i wiele osób liczyło na to, że dostanie coś z ziemi czy dobytku po wysiedlonych. Wskazuje się również prywatne układy, które sprawiały, że niektóre osoby były chronione przed wywózką, a zamiast nich brano - zazwyczaj losowo - inne, dopisując im wymyślone lub cudze przewinienia.

Niczym nie zawiniliśmy. A po prostu powiedzieli, oni tak napisali, że tata nosił jajka banderom do lasu. Ale to wcale tak nie było. My nie wiedzieliśmy [że będą wysiedlać - I.T.]. Nie, nie, nie. Nie uprzedzali, nie. Tu mieli wysiedlić jednego mężczyznę. On pracował w sklepie. Miał sklep i ośmioro dzieci. A jego rodzony brat był w [więzieniu - I.T.] ... w banderach, jego rodzony brat. A oni mieli tego Iwana wysiedlić, Ilka, nazywał się Ilko. Mieli go wysiedlić, ale przewodniczący wiejskiej rady był z nim w dobrych stosunkach. Przyjaźnił się z nim. Powiedział więc, aby wysiedlili mojego tatę zamiast niego. A jego zostawił, choć jego rodzony brat był w banderach, a mój tata niewinny był. Ale wysłał, wysłał nieszczęśnika i wsio.

W opowieściach o latach powojennych na Huculszczyźnie rozgrywa się konflikt dwóch sił zewnętrznych, bezosobowych, różniących się tylko nazwą. Wieś jest w tym konflikcie jedynie tłem, a ludzie w niej mieszkający tylko pionkami. Koszmar, w jakim przyszło żyć rozmówcom, jest wynikiem całkowitego odebrania im poczucia sprawczości oraz podmiotowości.

To opowieść nieheroiczna o ludziach, którzy nie walczyli zbrojnie w imię wyznawanych przez wspólnotę wartości - jak w bohaterskich mitach narodowych - lecz cierpieli jako niewinne ofiary w scenariuszach realizowanych przez zewnętrzne wobec nich siły i ideologie (Engelking 2012: 760).

Życie przedstawiane jest jako tragiczne w dosłownym sensie tego słowa. Niczym bohaterowie Ajschylosa czy Eurypidesa, przyszli Zesłańcy w starciu z partyzantką i moskalami skazani są na porażkę. Każdy wybór prowadzi do klęski, a żadnego de facto nie można podjąć. Nie opowiadając się po żadnej ze stron, można by liczyć na spokój, jednak nie było 
to dane rozmówcom, którzy nolens volnes wciągani byli w wir historii. Upowcom przychodzącym w nocy do chaty nie można odmówić jedzenia, jeśli chce się żyć. Podpisuje się tym samym wyrok na samych siebie u sowietów, którzy za tę pomoc przesiedlają na Sybir. Bezsilność i strach o własne życie, wyłaniające się z tych narracji, to ogromny ciężar, przygniatający rozmówców każdego dnia.

To jak nas wysiedlili, nie nas, ale wszystkich ludzi, których wysiedlali, to my byliśmy zadowoleni, że nas wysiedlili. Dzień jeszcze jak dzień, ale jak przyjdzie noc, to nie wiesz czy rana dożyjesz.

Wywózka uruchamia cały proces trajektoryjny - odpowiada punktowi (4) w Schützowskim schemacie. Moment aresztowania jest opisywany przez większość moich rozmówców dość zdawkowo - moskale przychodzą, mówią: „zbierajcie się“, dają chwilę na spakowanie, po czym zawożą do punktu zbornego. Aresztowanie jest niczym cięcie nożem - wyrywa z zawieszenia, bezsilności i czekania. Nadeszło jakieś rozwiązanie - moskale przyszli do chaty, a wraz z nimi nieznane.

Tak. Bardzo przykre było życie. Bardzo złe. A tak, jak nas wysiedlili, to my już byliśmy wolni. Nie smuciliśmy się. Przyjdzie noc, mogą stukać, a jak wyjdziecie z domu, to może ciebie zabić albo zabrać i gdzieś tam zabije.

Aresztowanie jest również momentem, w którym uwidaczniają się różnice majątkowe. Jedni odczuwają żal za zostawionymi dobrami, których już nie zobaczą. Inni z kolei nie mają niczego do zabrania ze sobą.

Przyszli w nocy i powiedzieli: „Zbierajcie się”. A co my mieliśmy wziąć? No co było do zabrania? To ani siebie nie odziejesz, ani nie masz co ze sobą wziąć. Nawet nie było żadnego koca.

Działania są ściśle określone: aresztowanie, pereselens 'ki punkt, podróż towarniakami. Głównym zadaniem staje się przeżycie i na nim skupiona jest cała energia wysiedlonych. Po przybyciu na miejsce zesłania ich „nowe życie" zaczyna się od podpisania dokumentu o wiecznym wysiedleniu. Ten symboliczny rozpis na vichnist' pojawia się w każdej wysłuchanej przeze mnie opowieści, tak samo jak niewyobrażalnie ciężkie warunki pierwszych miesięcy - a czasem lat - na zesłaniu. Są one kontynuacją procesu 
trajektoryjnego - próbami budowania nowej codzienności i odzyskiwania równowagi (etap 5 i 6 procesu opisanego przez Schützego). Te lata to nieustanna walka z głodem, chłodem, ciężkimi warunkami materialnymi, chorobami, widmem wszechobecnej śmierci.

Pewnego razu mama wróciła z pracy, i nie ma co dać dzieciom do jedzenia. Opowiadała mi potem, że wyszła i płakała. A tam była taka wielka rzeka Czułym. Ona powiedziała: „Skoczę w Czułym, niech dzieje się boża wola.“ Spotkała swojego naczelnika, który powiedział: „Gdzie ty tak idziesz i płaczesz?“ „Wróciłam z pracy i nie mam czym dzieci nakarmić.“ „Wracaj się.“ Zaprowadził ją do siebie do domu i powiedział żonie: „Zapakuj jedzenie do torby, ona nie ma czego dać dzieciom".

Ta poruszająca historia wskazuje również, w jakim tragicznym położeniu znajdowało się ,,pokolenie rodziców”. To na nich spoczywała odpowiedzialność za dzieci. To oni głównie doświadczali poczucia bezsilności, gdy nie można było wszystkim zapewnić jedzenia. Rozmówcy tej odpowiedzialności nie doświadczali. Kolejną różnicę między tymi dwoma pokoleniami obrazuje poniższa historia:

Opowiem wam o jednej babie. Taka staruszka, stąd z gór - Rożen, jest taka wieś Rożen. Ona każdego dnia przychodziła do centrum wsi. Tam było radio. Radio, które na całą wieś się roznosiło. Przekazywało nowiny, coś takiego. A ona biedna przychodziła, siadała i zawsze tego radia słuchała. I szła dalej, a potem wracała do swojej chaty i mówiła: „Słyszałam, w radio powiedzieli, że będą nas puszczać do domu. My wreszcie pojedziemy do domu". A wtedy jeszcze nas nie puszczali. Dopiero nas puścili, jak szlag boży trafił tego Stalina, czy kogo... No a ona biedna - jej się przywidywało. Jej się tak przywidywało, że ona u nas jest. I ona umarła tam taka biedna, na Sybirze umarła. I mąż jej umarł i ona też. Ona cały czas płakała, tak bardzo tęskniła za domem. Nie puszczali. Bardzo chciała wrócić do domu. Joj, jak ona płakała za swoimi górami.

Tęsknota rozmówczyni za Ukrainą była tak wielka, że paraliżowała jej wszelkie działanie. Bierność, nieprzystosowanie do nowej rzeczywistości, stało się przyczyną jej śmierci. Interlokutorzy rzadko wspominają, że tęsknili za ojczyzną. Zabrani z niej jako dzieci mogli jej po prostu nie pamiętać. Na pierwszy plan ich narracji wysuwa się raczej pozytywny autostereotyp, a mianowicie pracowitość Ukraińców czy Hucułów. Aby 
przeżyć, trzeba zmierzyć się z rzeczywistością tu i teraz. Pozostawanie myślami w przeszłości, oglądanie się wstecz, równoznaczne jest ze śmiercią. W narracjach rozmówców to właśnie praca staje się głównym sposobem okiełznania nowej rzeczywistości, a przez to środkiem do normalnego życia.

Przywieźli nas tutaj, pamiętam, do posiołka Pinia. Fińskie domki, w których nie było ani podłogi, ani piecy, niczego. Przywieźli i powiedzieli, że tu będziemy żyć. I Ukraińcy ruszyli do roboty. Dosłownie za miesiąc oni tam wszystko zrobili - i podłogi, i piece postawili. I zaczęli żyć.

Najbardziej interesującym aspektem zesłańczych narracji jest ich „pozytywny” wydźwięk. Oto mozolny, gigantyczny wysiłek codziennej, żmudnej pracy przynosi realne sukcesy i prowadzi do przywrócenia kontroli nad własnym życiem. Jako moment przejścia od okresu biedy do czasu, kiedy „łatwiej się żyje”, podaje się fakt zakupu krowy. Zesłańcy trzymali różne zwierzęta gospodarskie, kupowali również ziemię. Posiadanie tej ostatniej jest bardzo ważnym elementem chłopskiej tożsamości. Te początkowo przydomowe działki z czasem rozrastają się w całe gospodarstwa. Amerykański mit „od pucybuta do milionera” przybiera na Sybirze realną formę.

Jedno wam powiem - Ukraińcy to ludzie bardzo pracowici. Na przykład my mieliśmy krowę i konia, dwadzieścia cztery godziny na dobę, siedem dni w tygodniu mój tata obrabiał trzy hektary ziemi. Podatków my tam żadnych nie płaciliśmy. Wyobraźcie sobie, ile to jest trzy hektary. No, tutaj to nikt tyle nie ma, chyba że jacyś farmerzy. I pracowici byliśmy. Mój ojciec mówił: „O tu, jak jestem na Sybirze, to stałem się kułakiem".

Nieograniczami zewnętrznymi czynnikami Zesłańcy, a przynajmniej wielu z nich, własną ciężką pracą wywalczyli sobie nie tylko życie, ale również bogactwo.

W końcu życie było, w końcu pieniądze, już pracowaliśmy dużo, u nas... Uprawialiśmy ziemię, sadziliśmy kapustę, marchew, buraki, cebulę, rzodkiewkę. To drogo sprzedawaliśmy. Mieliśmy mnóstwo pieniędzy. Nawet stajnie postawiliśmy, już mieliśmy gęsi i krowy. To Huculi tak lubią, aby wszystko było i było. To z tego już... A tam tak nie... kto pracuje ten ma. No my bardzo ciężko pracowaliśmy. 
No ale wszystko mieliśmy. Wszystko mieliśmy i z tego tam żyliśmy. Tak, że mieliśmy mnóstwo pieniędzy. Tak, że już nic, niczym się nie martwiliśmy. No i dzieci takie jak my, to nie chciały jechać. Mama powiedziała: ,jedziemy”, no i wsio.

Codzienne życie bez głodu i biedy przywraca jednostkom sprawczość, budując ich nową tożsamość jako kowali swojego losu. Stają się ludźmi, którzy własnymi rękami odcisnęli ślad w otaczającej ich przestrzeni.

Kolej w tajdze robili ludzie. O tak. Zrobili. To taki był ten posiołek po 9 latach, tam gdzie ten las rąbali, tajgę. To taki posiołek - 12 ulic było, szkoła, wszystko było, sklepy. Ja nie mogę powiedzieć, że to było tylko tak że... pieniędzy nie było. Bo jak kobieta sama, to ona nie może zarobić na te dzieci. Ale ludzie, ci którzy byli pełnymi rodzinami [wysiedleni - I.T.], to oni wracali z pieniędzmi. Z zapasami stamtąd jechali. Żyć można było.

Narracje te, ujmując w kategoriach Fritza Schützego, są zdecydowanie opowieściami o (etap $7 \mathrm{w}$ jego schemacie) uzyskaniu kontroli nad trajektorią. Pomimo bezwolnego wrzucenia w bieg wydarzeń, odpowiedzią na chaos losu nie jest milczące cierpienie, bierność czy poddanie się, ale walka - i to nie tylko z zewnętrznymi okolicznościami, lecz również z samym sobą. Moi rozmówcy wywalczyli sobie dostatnie życie na Sybirze. Nierzadko zdobyli tam wykształcenie i majątki. Chcieli żyć i doświadczać życia w jego pełni - nie tylko przetrwać, ale również kreować, tworzyć, zmieniać, być we wspólnocie. Według Rocha Sulimy ,jest to obraz społeczności [...] nieustannie gotowej do odtworzenia się, a więc wyrażającej się w akcie »niszczenia« $\mathrm{i} » b u d o w a n i a \ll, ~ a k c i e ~ » u t r a-$ ty« i »odzyskania«" (cyt. za: Engelking 2012: 760).

Ten akt odtworzenia i budowania dokonuje się na Sybirze, gdzie Zesłańcy mogą wyzwolić się z poprzedniej sytuacji i gdzie zostaje im przywrócone poczucie sprawczości. Rozmówcy własnymi rękami zbudowali całe miasteczka. Ich wysiłek odzwierciedla się i materializuje $\mathrm{w}$ przestrzeni. I choć jest to budowanie dosłownie $\mathrm{z}$ niczego i w niewyobrażalnie ciężkich warunkach, to jednak stanowi dowód, że dzięki ogromnemu wysiłkowi i pracowitości można sobie wywalczyć normalne życie. Samoodtworzenie społeczności nie kończy się na materialnym dobrobycie. Na Sybirze Zesłańcy stworzyli swoją własną „małą Huculszczyznę", wraz z jej bogatymi tradycjami, tylko nie tak biedną, jak ją zapamiętali z dzieciństwa. 
W swoich autobiografiach, choć opisujących wiele ciężkich przeżyć, Zesłańcy nie opowiadają o traumie. Kluczowy sens ich narracji nie sprowadza się do postrzegania siebie jako ofiar, a na pewno nie jako ofiary zesłania. Ich tożsamość zasadza się na głębokim przekonaniu o własnej pracowitości oraz wyrastającym z niej poczuciu sprawczości: walczyli z zewnętrznymi okolicznościami, aktywnie je zmieniając. Było to jednak możliwe dopiero na Sybirze, co prowadzi do negatywnej oceny okresu przed wysyłką. Narracje (i oparte na nich poczucie tożsamości) wpływają na pamięć indywidualną. Okres sprzed wywózki musi być skonstruowany w jednoznacznie negatywny sposób, aby ukazać wieloznaczność doświadczenia sybirskiego.

Ich zbiorowej tożsamości w żadnym wypadku nie można sprowadzać do poczucia krzywdy. Ma ona bowiem niezwykle istotny drugi biegun: realizowany dzięki pracy sakralny wzór chłopa-gospodarza. Dzisiejszy kołchoźnik, tak samo jak dawny gospodarz, spełnia się, dążąc do tego fundamentalnego dla chłopskiej podmiotowości ideału. Ideał ten został wprawdzie ustanowiony przez mityczny i społeczny „los”, lecz jego urzeczywistnianie zależy od woli, a także aktywności jednostek (Engelking 2012: 761).

Choć Anna Engelking prowadziła swoje wieloletnie badania na Białorusi, skupiając się na doświadczeniu kołchoźników, sądzę, że jej słowa można również odnieść do terenu Huculszczyzny i narracji zesłańczych. Rozpatrywanie opowieści osób deportowanych na Sybir w kontekście religijności i etosu chłopskiego zdecydowanie wymaga szerzej zakrojonych badań, gdyżkwestie te daleko wykraczają poza doświadczenie zesłania i dotyczą tożsamości chłopskiej jako takiej. Niemniej to właśnie sprawczość, praca oraz wkładany w zmianę rzeczywistości wysiłek są głównymi rysami w narracjach moich rozmówców.

\section{Próba odpowiedzi}

Znając odpowiedź na pierwsze $\mathrm{z}$ postawionych przeze mnie na początku pytań - jak swoje doświadczenie rozumieją sami Zesłańcy z huculszczyzny - możemy pokusić się o próby odpowiedzi na kolejne dwa: dlaczego podobne doświadczenia tak odmiennie zachowały się w pamięci dwóch narodów i dlaczego dla Polaków Sybir był traumą, a dla Hucułów wyzwoleniem? 
Odpowiadając na pierwsze $\mathrm{z}$ nich, musimy odwołać się do kategorii pamięci. Choć napisano o niej wiele ${ }^{21}$, szczególnie pomocne tu będą kategorie wypracowane przez Jana i Aleidę Assmann (Assmann A. 2009, Assmann J. 2008): pamięć komunikatywna, pokoleniowa, pamięć zbiorowa, pamięć kulturowa. O ile dwa pierwsze typy pamięci są w teorii niemieckich badaczy rozumiane jako będące na jednym poziomie - tworzone w sposób spontaniczny i oddolny, oparte na komunikacji międzyludzkiej, znikające wraz ze śmiercią ich przekazicieli, o tyle dwa ostatnie są już niejako kolejnymi poziomami - pamięć zbiorowa to upolityczniona długoterminowa pamięć społeczna, a pamięć kulturowa jest konstruowana w oparciu o media i instytucje.

Pamięć i zbiorowość wspierają się nawzajem: zbiorowość jest nośnikiem pamięci, a pamięć stabilizuje zbiorowość. [...] Pamięć zbiorowa jest pamięcią polityczną. W przeciwieństwie do rozproszonej pamięci komunikatywnej, która sama się kształtuje i sama się rozpada, pamięć zbiorowa kierowana jest z zewnątrz i charakteryzuje się wysokim stopniem jednolitości (Assmann 2009: 163).

Różnica pomiędzy huculskimi narracjami a polskim dyskursem dotyczącym zesłań polega według mnie właśnie na tym: pierwsze to narracje, pamięć pokolenia, w której „odmienne wspomnienia jednostkowe uśredniają się do zbiorowego tła doświadczeniowego" (Assmann 2009: 160), są spontanicznym wyrazem tożsamości grupowej kreowanej oddolnie przez samych Zesłańców, a druga to pamięć zbiorowa i kulturowa, która jest upolityczniona, wspierana przez szereg instytucji i zaangażowana w tworzenie polskiego dyskursu historycznego. Odpowiednika polskiej pamięci zbiorowej czy kulturowej na Ukrainie można szukać w pamięci Łagierników, których większość trafiła do obozów ze względu na swoją działalność w Ukraińskiej Powstańczej Armii, ale oczywiście wymaga to szerzej zakrojonych badań ukraińskiego dyskursu historycznego. Ciekawym tropem byłaby również próba porównania huculskich narracji o zesłaniu z narracjami o tych wydarzeniach $\mathrm{z}$ innych regionów Ukrainy.

Pamięć Zesłańców, która, jak sądzę, obraca się na poziomie pamięci pokoleniowej czy grupowej, pozostawia rozmówcom przestrzeń na alternatywną wersję opowieści o zesłaniu - opowieść o zesłaniu bez

${ }^{21}$ Obszerny przegląd literatury na ten temat przedstawiają: Ratkowska-Widlarz (2011), Kaniowska (2003), Saryusz-Wolska (2009), Wylegała (2014). 
traumy. I tu nasuwa się odpowiedź na ostatnie pytanie, o różnicę w rozumieniu zesłania jako traumy lub jako wyzwolenia. Polskie narracje o zesłaniu są bardzo silnie zinstytucjonalizowane, wpisując się w szerszy proces historycznego konstruowania polskiej tożsamości, opartej głównie na poczuciu narodowej misji i martyrologicznym utożsamieniu się z Chrystusem narodów. Cierpienie stanowi w nich wątek przewodni, tak samo jak w „tradycyjnych” wyobrażeniach i konstrukcjach polskości jako takiej ${ }^{22}$. Czynnikiem wyznaczającym różnice między tymi dwiema opowieściami jest również potencjalna możliwość powrotu z zesłania. W polskich narracjach podkreśla się stałe dążenie do powrotu, tęsknotę, widoczna jest ich koncentracja na utraconym domu. Te huculskie zawierają w sobie symboliczną cezurę [rozpis na vichnist'], która sprawia, że powrót przestaje być rozważany jako realna możliwość.

A nas po dziesięciu latach puścili. Ale jak nas przywieźli, to były takie wielkie arkusze u komendanta i musieliśmy podpisać, że na całe życie. Na wieczność. Tak, że my będziemy wiecznie wysiedleni. Rozumiesz?

Kolejnym poziomem tworzącym różnice pomiędzy odmiennymi przedstawieniami zesłania - traumy bądź wyzwolenia - jest kontekst klasowy. Polacy wywożeni na Sybir byli przeważnie inteligentami, urzędnikami, post-ziemianami, reprezentantami klasy średniej i wyższej. Ich opowieści przedstawiają tragedię wyrwania z „idylli życia kresowego”, całkowitą destrukcję tego świata oraz wrzucenie w obcą, nieprzyjazną przestrzeń, która wydaje się piekłem. Zesłanie często jest też dla nich miejscem, gdzie po raz pierwszy stykają się z ciężką, niekiedy ponad siły, pracą fizyczną.

Opowieści huculskie to opowieści chłopskie, dla których praca i ziemia są jednymi z podstawowych kategorii. Praca postrzegana jest jako wyzwolenie od biedy, doświadczanej zarówno przed, jak i na początku zesłania. To ona diametralnie zmienia życie Zesłańców, przywracając im poczucie sprawczości, którego byli pozbawieni na (tużpowojennej) Ukrainie. Stają się - w dosłownym sensie - kowalami własnego losu. Wyłącznie od nich zależy, czy zdobędą pieniądze, a wraz z nimi zapewnią sobie lepszy byt. Dla moich rozmówców, którzy wcześniejsze życie przedstawiają jako związane $\mathrm{z}$ ciągłym strachem, pozbawieniem

${ }^{22}$ Oczywiście absolutnie nie neguję tu tragedii i ciężaru wydarzeń, które spotkały zesłańców. 
Zesłanie jako wyzwolenie - narracje z Huculszczyzny

poczucia podmiotowości i brakiem jakichkolwiek możliwości działania - to właśnie Sybir, choć wydaje się to może paradoksalne, stał się wyzwoleniem - szansą na ,normalne” życie.

Wszystko jedno, że nas wysiedlili. Ja świat zobaczyłam. A tak to bym żyła tutaj w Z., w tym kątku, całe życie, nic bym nie wiedziała. A tak nażyłam się, nabawiłam się - zewsząd. I nie było biedy, nam bardzo dobrze tam było.

\section{BIBLIOGRAFIA}

Assmann, A. (2009). 1998 - Między historią a pamięcią. W: M. Saryusz-Wolska (red.), Pamięć zbiorowa i kulturowa. Wspótczesna perspektywa niemiecka, s. 143 - 173. Kraków: Towarzystwo Autorów i Wydawców Prac Naukowych Universitas.

Assmann, J. (2008). Pamięć kulturowa: pismo, zapamiętywanie i polityczna tożsamość w cywilizacjach starożytnych (przeł. A. Kryczyńska-Pham). Warszawa: Wydawnictwa Uniwersytetu Warszawskiego.

Buhay, N.F. (2006). Narody Ukrainy v „, Osoboy papke Stalina”. Moskva: Nauka. Ciesielski, S. (2001). Masowe deportacje w ZSRR - charakterystyka wybranych aspektów zjawiska. Dzieje Najnowsze: kwartalnik poświęcony historii XX wieku, 3, 29-56.

Ciesielski, S., Hryciuk G. Srebrakowski A. (2004). Masowe deportacje ludności w Zwiazku Radzieckim. Toruń: Wydawnictwo Adam Marszałek.

Engelking, A. (2012). Kołchoźnicy. Antropologiczne studium tożsamości wsi białoruskiej przełomu XX i XXI wieku. Torun: Wydawnictwo Naukowe Uniwersytetu Mikołaja Kopernika.

Hrycak J. (2000). Historia Ukrainy 1772-1999. Narodziny nowoczesnego naro$d u$. Lublin: Instytut Europy Środkowo-Wschodniej.

Kaniowska, K. (2003). Antropologia i problem pamięci. Konteksty. Polska Sztuka Ludowa, 3-4, 59-65.

Kudela-Świątek, W. (2013). Odpamiętane. O historii mówionej na przyktadzie narracji kazachstańskich Polaków o represjach na tle narodowościowym i religijnym. Kraków: Towarzystwo Autorów i Wydawców Prac Naukowych Universitas.

Kość, K. (2008). Żywi we wspomnieniach. Doświadczenia śmierci w relacjach polskich zestańców w ZSRR (w latach 1940-1946). Wrocław: Polskie Towarzystwo Ludoznawcze. 
Polian, P. (2003). Against Their Will. The History and Geography of Forced Migrations in the USSR. Budapest, New York: CEU University Press.

Ratkowska-Widlarz, L. (2011). Narracje (relacje świadków) w warsztacie antropologa kultury. Pamięć i Antropologia. Wrocławski Rocznik Historii Mówionej, I, 35-56.

Rokuszewska-Pawełek, A. (2002). Chaos i przymus. Trajektorie wojenne Polaków. Łódź: Wydawnictwo Uniwersytetu Łódzkiego.

Rzepkowska, A. (2009). Sybiracy: Wspólnota - Pamięć - Narracja. Studium antropologiczne. Łódź: Polskie Towarzystwo Ludoznawcze.

Rzepkowska, A. (2008). Słuchając wspomnień Sybiraków. Antropolog wobec doświadczenia zesłania. Lud, 92, 13-26.

Saryusz-Wolska, M. (red.) (2009). Pamięć zbiorowa i kulturowa. Współczesna perspektywa niemiecka. Kraków: Towarzystwo Autorów i Wydawców Prac Naukowych Universitas.

Saryusz-Wolska, M., Traba, R. (red.). (2014). Modi memorandi. Leksykon kultury pamięci. Warszawa: Wydawnictwo Naukowe Scholar.

Stecenko, N. (2007). Nasyl'nytsk'e vyselennya naselennya zakhidnoukrayin'skykh zemel' u 1940-1950-kh rokakh. Visnyk kyyivs'koho natsional'noho universytetu imeni tarasa shevchenka, 91-93. Pozyskano z http://papers. univ.kiev.ua/istorija/articles/The_expulsion_by_force_of_the_population of_the_Western_Ukrainian_lands_in_1940_th_1950_th_15430.pdf.

Trzebiński, J. (red.). (2002). Narracja jako sposób rozumienia świata. Gdańsk: Gdańskie Wydawnictwo Psychologiczne.

Wronsska, T. W. (2007). Pravovi osnovy derzhavnoho teroru proty rodyn uchasnykiv povstans'koho rukhu $\mathrm{v}$ Zakhidniy Ukrayini. Z arkhiviv VUCHK-HPU-NKVD-KHB, 29, 134-159.

Wylegała, A. (2014). Przesiedlenia a pamięć. Toruń: Wydawnictwo Naukowe Uniwersytetu Mikołaja Kopernika.

Vynnychenko, I. (1994). Ukrayina 1920-1980-kh deportatsiyi, zaslannya, vyslannya. Kyjiv: Vydavnytstvo Rada. 